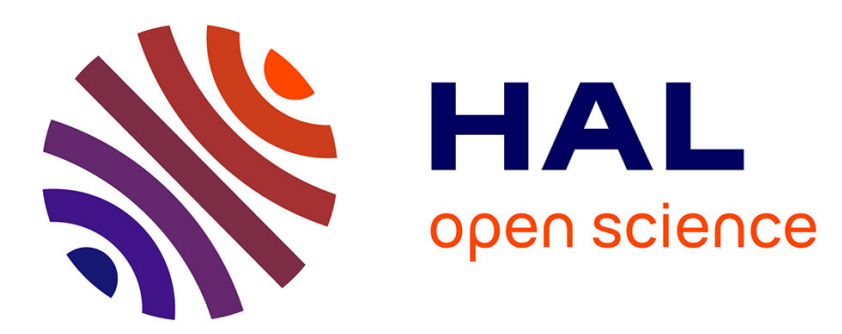

\title{
Radiative forcing due to changes in ozone and methane caused by the transport sector
}

\author{
G. Myhre, K.P. Shine, G. Rädel, M. Gauss, I.S.A. Isaksen, Q. Tang, M.J. \\ Prather, J.E. Williams, P. van Velthoven, O. Dessens, et al.
}

\section{- To cite this version:}

G. Myhre, K.P. Shine, G. Rädel, M. Gauss, I.S.A. Isaksen, et al.. Radiative forcing due to changes in ozone and methane caused by the transport sector. Atmospheric Environment, 2011, 45 (2), pp.387394. 10.1016/J.ATMOSENV.2010.10.001 . hal-03048479

\section{HAL Id: hal-03048479 \\ https://hal.science/hal-03048479}

Submitted on 10 Dec 2020

HAL is a multi-disciplinary open access archive for the deposit and dissemination of scientific research documents, whether they are published or not. The documents may come from teaching and research institutions in France or abroad, or from public or private research centers.
L'archive ouverte pluridisciplinaire HAL, est destinée au dépôt et à la diffusion de documents scientifiques de niveau recherche, publiés ou non, émanant des établissements d'enseignement et de recherche français ou étrangers, des laboratoires publics ou privés. 


\section{UC Irvine}

\section{Faculty Publications}

\section{Title}

Radiative forcing due to changes in ozone and methane caused by the transport sector

Permalink

https://escholarship.org/uc/item/8th5h75w

\section{Journal}

Atmospheric Environment, 45(2)

\section{ISSN}

13522310

\section{Authors}

Myhre, G.

Shine, K.P.

Radel, G.

et al.

\section{Publication Date}

2011

\section{DOI}

10.1016/j.atmosenv.2010.10.001

\section{License}

https://creativecommons.org/licenses/by/4.0/4.0

Peer reviewed 


\title{
Radiative forcing due to changes in ozone and methane caused by the transport sector
}

\author{
G. Myhre $^{\mathrm{a}, \mathrm{b}, *}$, K.P. Shine ${ }^{\mathrm{c}}$, G. Rädel ${ }^{\mathrm{c}}$, M. Gauss ${ }^{\mathrm{b}, \mathrm{k}}$, I.S.A. Isaksen ${ }^{\mathrm{a}, \mathrm{b}}$, Q. Tang ${ }^{\mathrm{d}}$, M.J. Prather ${ }^{\mathrm{d}}$, \\ J.E. Williams ${ }^{\text {e }}$, P. van Velthoven ${ }^{\text {e }}$, O. Dessens ${ }^{f}$, B. Koffi ${ }^{g}$, S. Szopa ${ }^{g}$, P. Hoor ${ }^{\text {h }}$, \\ V. Grewe ${ }^{\mathrm{i}}$, J. Borken-Kleefeld ${ }^{\mathrm{j}, 1}$, T.K. Berntsen ${ }^{\mathrm{a}, \mathrm{b}}$, J.S. Fuglestvedt ${ }^{\mathrm{a}}$ \\ ${ }^{a}$ Center for International Climate and Environmental Research-Oslo (CICERO), Oslo, Norway \\ ${ }^{\mathrm{b}}$ Department of Geosciences, University of Oslo, Norway \\ ${ }^{\mathrm{c}}$ Department of Meteorology, University of Reading, Reading, UK \\ ${ }^{\mathrm{d}}$ Earth System Science Dept., UC Irvine, CA, USA \\ ${ }^{\mathrm{e}}$ Chemistry-Climate Division, Royal Netherlands Meteorological Institute, The Netherlands \\ ${ }^{\mathrm{f}}$ Centre for Atmospheric Science, Dept. of Chemistry, Cambridge, UK \\ ${ }^{g}$ Laboratoire des Sciences du Climat et de l'Environnement (LSCE-IPSL), Gif-sur-Yvette, France \\ ${ }^{\mathrm{h}}$ Institute for Atmospheric Physics, University Mainz, Germany \\ ${ }^{\mathrm{i}}$ Deutsches Zentrum für Luft- und Raumfahrt, Institut für Physik der Atmosphäre, Oberpfaffenhofen, Germany \\ ${ }^{\mathrm{j}}$ Formerly: Deutsches Zentrum für Luft- und Raumfahrt, Verkehrsstudien, Berlin, Germany \\ ${ }^{\mathrm{k}}$ Norwegian Meteorological Institute, Oslo, Norway
}

\section{A R T I C L E I N F O}

\section{Article history:}

Received 19 May 2010

Received in revised form

27 September 2010

Accepted 4 October 2010

\section{Keywords:}

Radiative forcing

GWP

GTP

Shipping

Aviation

Road transport

\begin{abstract}
A B S T R A C T
The year 2000 radiative forcing ( $\mathrm{RF}$ ) due to changes in $\mathrm{O}_{3}$ and $\mathrm{CH}_{4}$ (and the $\mathrm{CH}_{4}$-induced stratospheric water vapour) as a result of emissions of short-lived gases (oxides of nitrogen $\left(\mathrm{NO}_{\mathrm{x}}\right)$, carbon monoxide and non-methane hydrocarbons) from three transport sectors (ROAD, maritime SHIPping and AIRcraft) are calculated using results from five global atmospheric chemistry models. Using results from these models plus other published data, we quantify the uncertainties. The RF due to short-term $\mathrm{O}_{3}$ changes (i.e. as an immediate response to the emissions without allowing for the long-term $\mathrm{CH}_{4}$ changes) is positive and highest for ROAD transport $\left(31 \mathrm{~mW} \mathrm{~m}^{-2}\right)$ compared to SHIP $\left(24 \mathrm{~mW} \mathrm{~m}^{-2}\right)$ and AIR $\left(17 \mathrm{~mW} \mathrm{~m}^{-2}\right.$ ) sectors in four of the models. All five models calculate negative $\mathrm{RF}$ from the $\mathrm{CH}_{4}$ perturbations, with a larger impact from the SHIP sector than for ROAD and AIR. The net RF of $\mathrm{O}_{3}$ and $\mathrm{CH}_{4}$ combined (i.e. including the impact of $\mathrm{CH}_{4}$ on ozone and stratospheric water vapour) is positive for ROAD $\left(+16( \pm 13)\right.$ (one standard deviation) $\left.\mathrm{mW} \mathrm{m}^{-2}\right)$ and AIR $\left(+6( \pm 5) \mathrm{mW} \mathrm{m}^{-2}\right)$ traffic sectors and is negative for SHIP $\left(-18( \pm 10) \mathrm{mW} \mathrm{m}^{-2}\right)$ sector in all five models. Global Warming Potentials (GWP) and Global Temperature change Potentials (GTP) are presented for AIR $\mathrm{NO}_{\mathrm{x}}$ emissions; there is a wide spread in the results from the 5 chemistry models, and it is shown that differences in the methane response relative to the $\mathrm{O}_{3}$ response drive much of the spread.
\end{abstract}

(c) 2010 Elsevier Ltd. All rights reserved.

\section{Introduction}

The climate impact of the transport sector occurs through emissions of $\mathrm{CO}_{2}$, aerosols (and their precursors), water vapour, and species that affect ozone and the oxidative state of the atmosphere

\footnotetext{
* Corresponding author. Center for International Climate and Environmental Research-Oslo (CICERO), Oslo, Norway.

E-mail address: gunnar.myhre@cicero.uio.no (G. Myhre).

1 Now at: International Institute for Applied Systems Analysis, Laxenburg Austria.
}

such as $\mathrm{NO}_{\mathrm{x}}, \mathrm{CO}$ and non-methane hydrocarbons (NHMC), with direct emissions of $\mathrm{CH}_{4}$ being negligible for these sectors. This paper examines the impact of this latter class of oxidant emissions from three transport sub-sectors - land transport (ROAD), maritime shipping (SHIP) and aviation (AIR). We calculate the radiative forcing (RF) by considering both short-term and long-term changes in atmospheric composition. The estimated RF due to all emissions is positive for ROAD and AIR, but negative for SHIP (Fuglestvedt et al., 2008). This switch for SHIP is partly due to the strong direct and indirect aerosol effect from SHIP (Balkanski et al., 2010; Fuglestvedt et al., 2008) but also a result of the high $\mathrm{NO}_{\mathrm{x}}$ emissions which reduce the $\mathrm{CH}_{4}$ lifetime. This coupling in the atmospheric 
chemistry between $\mathrm{NO}_{\mathrm{x}}, \mathrm{CH}_{4}$, and $\mathrm{O}_{3}$ is well established (Fuglestvedt et al., 1999; Lelieveld et al., 1998; Naik et al., 2005; Shindell et al., 2005, 2009; Wild and Prather, 2000). Emissions of the short-lived trace gas species $\mathrm{NO}_{\mathrm{x}}$, non-methane hydrocarbons (NMHC), and $\mathrm{CO}$ lead to production of tropospheric $\mathrm{O}_{3}$, and we denote this as the short-term $\mathrm{O}_{3} \mathrm{RF}$. The reduction in $\mathrm{CH}_{4}$ also leads to additional changes in $\mathrm{O}_{3}$, but due to the long lifetime of $\mathrm{CH}_{4}$ compared to the other $\mathrm{O}_{3}$ precursors, this change in $\mathrm{O}_{3}$ occurs on a longer time-scale than the short-term $\mathrm{O}_{3} \mathrm{RF}$ (Prather, 1994; Wild et al., 2001). We denote the change in $\mathrm{O}_{3}$ from $\mathrm{CH}_{4}$ changes as the $\mathrm{CH}_{4}$-induced $\mathrm{O}_{3}$ change.

The $\mathrm{RF}$ from $\mathrm{O}_{3}$ changes since pre-industrial time is estimated to be $0.35 \mathrm{~W} \mathrm{~m}^{-2}$ (Forster et al., 2007; Gauss et al., 2006) and the transport sectors have been estimated to contribute as much as a third of this value (Fuglestvedt et al., 2008). In terms of RF, the reduction in the $\mathrm{CH}_{4}$ lifetime from $\mathrm{NO}_{\mathrm{x}}$ emissions acts on a global scale in opposition to the positive RF due to $\mathrm{O}_{3}$ production from $\mathrm{NO}_{\mathrm{x}}$, leading to a smaller net effect of $\mathrm{NO}_{\mathrm{x}}$ (Forster et al., 2007; Shindell et al., 2005; Wild et al., 2001).

Sector-specific analyses of RF are important, particularly when mitigation measures are being considered because each sector's impact is unique. This is especially relevant for the transport sectors where the emissions are introduced into quite different environments - road emissions are predominantly released into the polluted boundary layer, ship emissions are mostly released into the clean maritime boundary layer, and aircraft emissions are mostly released into the upper troposphere and lower stratosphere. Using several global atmospheric chemistry models and radiative transfer schemes, we quantify the RF resulting from changes in $\mathrm{O}_{3}$ and the $\mathrm{CH}_{4}$ lifetime due to emissions of $\mathrm{NO}_{\mathrm{x}}, \mathrm{CO}$ and NMHCs from the different transport sectors. We focus on the sign of the net RF and its uncertainty for the three transport sectors. The results can be used, together with calculations of the forcing due to other emissions (e.g. $\mathrm{CO}_{2}$ and black carbon) from the transport sector, to assess and quantify the overall climate impact of each sector (e.g. Skeie et al., 2009).

This paper presents results from the European Union project QUANTIFY (Quantifying the Climate Impact of Global and European Emission Systems). Hoor et al. (2009) reported an analysis of preliminary QUANTIFY simulations, focusing on the behaviour of the different chemical models; they also included a brief discussion of the RF from the different transport sectors. The simulations reported here use the final revised QUANTIFY emission inventories, which were developed during the course of the project (Uherek et al., 2010). We concentrate on a more detailed analysis of the resulting RF and its associated uncertainty and on the computation of climate emissions metrics (Global Warming Potential (GWP) and Global Temperature change Potential (GTP)) for aviation $\mathrm{NO}_{\mathrm{x}}$ emissions. An estimate of current climate importance of the accumulated emissions from the transport sector up to year 2000 can be made using RF. To assess the future importance of current emissions and for considerations for mitigation purposes, forward looking emission metrics such as the GWP and the GTP metrics are more useful as they account for the persistence of atmospheric perturbations and thus the integrated impacts (Fuglestvedt et al., 2010).

\section{Methods and models}

Five global chemistry models consisting of four Chemistry Transport Models (CTMs) and one Climate Chemistry Model (CCM) have been used to simulate changes in $\mathrm{O}_{3}$ and $\mathrm{OH}$ due to precursor emissions $\left(\mathrm{NO}_{\mathrm{x}}, \mathrm{CO}\right.$, and $\left.\mathrm{NMHC}\right)$ from the different transport sectors with year 2000 emissions (see Table 1 for model descriptions). Each model ran with fixed $\mathrm{CH}_{4}$ abundances and then adopted a spin-up period of a year in order to attain chemical steady state with respect to $\mathrm{O}_{3}$. The imbalance in the $\mathrm{CH}_{4}$ budget is diagnosed; this allows the calculation of the change in $\mathrm{CH}_{4}$ abundance that would have occurred over decades if the emissions were held constant. The QUANTIFY methodology (see Hoor et al., 2009 and Grewe et al., 2010 for details) is to include all natural and anthropogenic emissions and then to compute the impact of an individual transport sector by reducing each respective sector's emissions by $5 \%$, so as to ensure that perturbations act on an atmosphere close to present-day composition (Grewe et al., 2010). The $5 \%$ results are scaled by a factor 20 to represent the total change attributable to the transport sectors. The difference between a $20 \times 5 \%$ reduction and a complete $100 \%$ reduction are discussed in Section 3.1. Fig. 1 compares the improved emissions used in this study compared to those of Fuglestvedt et al. (2008) and Hoor et al. (2009). ROAD emissions of $\mathrm{NO}_{\mathrm{x}}, \mathrm{NMHC}$ and $\mathrm{CO}$ are highest in Fuglestvedt et al. (2008), whereas the new QUANTIFY $\mathrm{NO}_{\mathrm{x}}$ emissions for AIR are greater than those in Fuglestvedt et al. (2008) and Hoor et al. (2009). Only Fuglestvedt et al. (2008) included CO and NMHC emissions for the AIR sector, but these emissions are negligible in terms of global anthropogenic sources. Note the much higher ratio of $\mathrm{NO}_{\mathrm{x}}$ to $\mathrm{CO}_{2}$ in SHIP and AIR emissions compared to ROAD emissions. The gridded emission data can be downloaded from www.ip-quantify.eu.

The RF calculations for the $\mathrm{O}_{3}$ changes from the chemical models are performed using two sets of radiative transfer models, University of Oslo (UiO) and University of Reading (UoR). Except where stated, the simulations here use the UiO schemes, which consist of a broad-band scheme for thermal infrared radiation and a scheme using the multi-stream DISORT code for shortwave radiation (Myhre et al., 2000). UoR have performed $\mathrm{O}_{3} \mathrm{RF}$ calculations using the $\mathrm{O}_{3}$ changes for each sector averaged over 4 of the global chemistry models (Oslo CTM2, TM4, LMDz-INCA and p-TOMCAT; the UCI results are a recent addition) using the Edwards

Table 1

A short description of the CTMs and CCM used in this study. A more detailed overview of the models is given in Hoor et al. (2009).

\begin{tabular}{|c|c|c|c|}
\hline Model acronym & Institution & Short description & Reference \\
\hline Oslo CTM2 & University of Oslo, Norway & $\begin{array}{l}\text { CTM driven by ECMWF meteorology } \\
\text { in T42 horizontal resolution and } 60 \text { vertical layers }\end{array}$ & $\begin{array}{l}\text { (Berglen et al., 2004; Gauss et al., 2006; } \\
\text { Isaksen et al., 2005) }\end{array}$ \\
\hline TM4 & KNMI, The Netherlands & $\begin{array}{l}\text { CTM driven by ECMWF meteorology } \\
\text { with a } 2^{\circ} \times 3^{\circ} \text { horizontal resolution and } 34 \text { vertical layers }\end{array}$ & $\begin{array}{l}\text { (van Noije et al., 2006; Williams et al., 2009; } \\
\text { Williams et al., 2010) }\end{array}$ \\
\hline p-TOMCAT & University of Cambridge, UK & $\begin{array}{l}\text { CTM driven by ECMWF meteorology } \\
\text { in T21 horizontal resolution and } 31 \text { vertical layers }\end{array}$ & (O’Connor et al., 2005) \\
\hline LMDz-INCA & LSCE, Gif sur Yvette, France & $\begin{array}{l}\text { CCM nudged to meteorological data } \\
\text { from ECMWF with a horizontal resolution } \\
\text { of } 3.75^{\circ} \times 2.5^{\circ} \text { and } 19 \text { vertical layers }\end{array}$ & (Folberth et al., 2006; Hauglustaine et al., 2004) \\
\hline UCI & University of California, Irvine, USA & $\begin{array}{l}\text { CTM driven by ECMWF meteorology } \\
\text { in T42 horizontal resolution and } 37 \text { vertical layers }\end{array}$ & (Hsu et al., 2005; Wild et al., 2003) \\
\hline
\end{tabular}



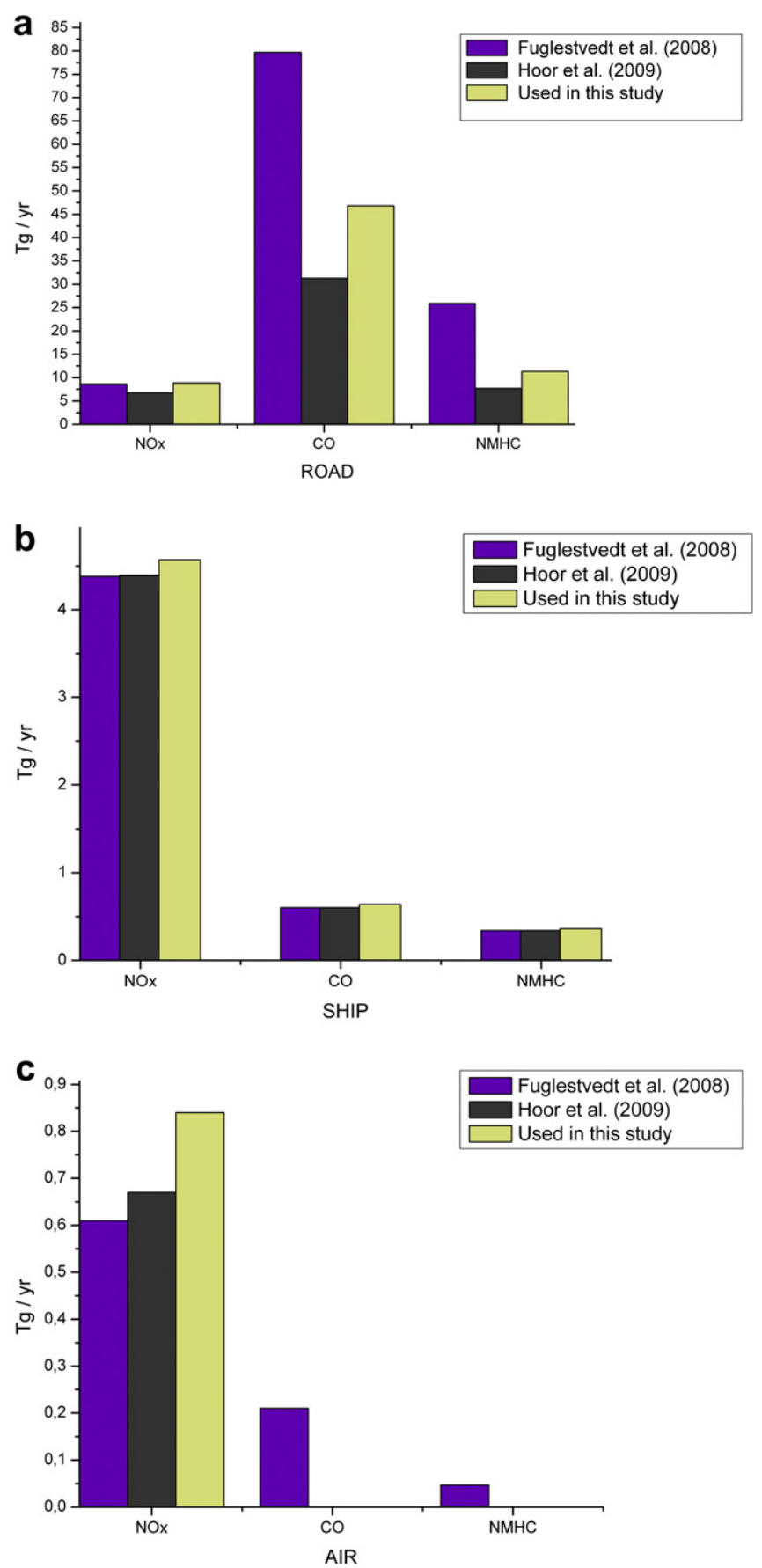

Fig. 1. Emissions (year 2000) of $\mathrm{O}_{3}$ precursors $\left(\mathrm{NO}_{\mathrm{x}}, \mathrm{CO}\right.$, and $\mathrm{NHMC}$ ) (given in $\mathrm{Tg}(\mathrm{N}) \mathrm{yr}^{-1}, \mathrm{Tg}(\mathrm{C}) \mathrm{yr}^{-1}$, and $\mathrm{Tg}(\mathrm{C}) \mathrm{yr}^{-1}$, respectively) for two previous studies (Fuglestvedt et al., 2008; Hoor et al., 2009) and in this study for ROAD (top), SHIP (middle) and $\mathrm{AIR}$ (bottom). For comparison, the $\mathrm{CO}_{2}$ emissions (as $\mathrm{CO}_{2}$ ) in year 2000 are $4200 \mathrm{Tg}, 622 \mathrm{Tg}$ and $677 \mathrm{Tg}$ for ROAD, SHIP, and AIR; respectively.

and Slingo (1996) two-stream radiation code, with 6 bands in the shortwave and 8 bands in the longwave.

The methodology for calculating the forcing due to $\mathrm{CH}_{4}$ changes follows the simple approach described by Berntsen et al. (2005) and used in Hoor et al. (2009), with two important extensions. The chemistry models do not explicitly calculate the change in $\mathrm{CH}_{4}$ concentrations and in any case the simulations are not long enough for the $\mathrm{CH}_{4}$ to come into equilibrium with the changed $\mathrm{OH}$ field. Instead, the change in $\mathrm{OH}$ is used to estimate the fractional change in $\mathrm{CH}_{4}$ lifetime. This is then multiplied by the present-day concentration of methane and a model-average feedback factor of 1.4 (Prather et al., 2001), to account for the impact of changes in $\mathrm{CH}_{4}$ concentration on its own lifetime, to yield the fractional change in $\mathrm{CH}_{4}$ concentration for steady-state conditions (Fuglestvedt et al., 1999). The QUANTIFY study did not directly calculate this feedback factor, nor the increase in tropospheric $\mathrm{O}_{3}$ per change in $\mathrm{CH}_{4}$, so we resort to the published, model-average values here.

The $\mathrm{RF}$ is calculated assuming a specific $\mathrm{CH}_{4} \mathrm{RF}$ of $0.37 \mathrm{~mW} \mathrm{~m}^{-2} \mathrm{ppbv}^{-1}$, which assumes a background concentration of $1740 \mathrm{ppb}$. The $\mathrm{CH}_{4}$-induced $\mathrm{O}_{3} \mathrm{RF}$ is then computed, following Berntsen et al. (2005) and using results from Prather et al. (2001), whereby a $10 \%$ increase in $\mathrm{CH}_{4}$ leads to a $0.64 \mathrm{DU}$ increase in $\mathrm{O}_{3}$, and this $\mathrm{O}_{3}$ has a specific RF of $42 \mathrm{~mW} \mathrm{~m}^{-2} \mathrm{DU}^{-1}$ (Ramaswamy et al., 2001); this RF factor is more applicable to the global-scale change in tropospheric $\mathrm{O}_{3}$ resulting from the methane change, than it is to the more regional short-term ozone change resulting from transport sector emissions.

The first extension to the Hoor et al. (2009) methodology is to account for the impact of $\mathrm{CH}_{4}$ changes on stratospheric water vapour. Based on Myhre et al. (2007), we take the stratospheric water vapour $\mathrm{RF}$ to be 0.15 times that of the $\mathrm{CH}_{4} \mathrm{RF}$. The second extension to the Hoor et al. (2009) methodology is to relax the assumption that the $\mathrm{CH}_{4}$ concentration in 2000 is in steady state with that year's change in $\mathrm{OH}$. The actual degree of imbalance depends on the history of change in $\mathrm{OH}$, which is not accounted for in the chemical model calculations which used year 2000 emissions. The degree of imbalance will be greatest for AIR, for which the emissions have been growing most rapidly in recent years, and least for ROAD. The method and assumptions about the historical emissions are described in Grewe and Stenke (2008). The factor to correct this transient response in year 2000 is taken to be 0.85 for ROAD, 0.8 for SHIP and 0.65 for AIR. These factors are then applied to the $\mathrm{CH}_{4} \mathrm{RF}$, the $\mathrm{CH}_{4}$-induced $\mathrm{O}_{3} \mathrm{RF}$ and the stratospheric water vapour RF from each of the CTMs. These corrections to the instantaneous year $2000 \mathrm{RF}$ are a result of the historical emissions and do not apply to the calculation of GWP and GTP for AIR in Section 4.

Other consequences of the $\mathrm{O}_{3}$ precursor emissions have been identified but are not considered here. For example, changes in $\mathrm{O}_{3}$ and $\mathrm{OH}$ may alter the sulphate burden (e.g. Unger et al., 2006; Shindell et al., 2009) and surface $\mathrm{O}_{3}$ interaction with vegetation may impact the carbon cycle (Sitch et al., 2007). $\mathrm{NO}_{\mathrm{x}}$ emissions have a small direct RF due to the absorption of solar radiation by $\mathrm{NO}_{2}$ (Kvalevåg and Myhre, 2007) and formation of nitrate aerosols from the $\mathrm{NO}_{\mathrm{x}}$ enhances the overall aerosol negative RF (Forster et al., 2007). This paper focuses on the primary, well-established impacts of the ozone-precursor emissions on $\mathrm{O}_{3}$ and $\mathrm{CH}_{4}$ and their consequential effects.

\section{Results}

\subsection{Short-term $\mathrm{O}_{3}$}

Table 2 compares the global and annual mean total column $\mathrm{O}_{3}$ change (in DU) for the five global chemistry models and the three transport sectors for the QUANTIFY preliminary emissions (Hoor et al., 2009) and QUANTIFY final emissions used here. The largest changes in the $\mathrm{O}_{3}$ column between the simulations using the preliminary and final emissions are seen for ROAD and AIR. In addition to changes in the emissions inventories, there have also been model improvements and updates by many of the modelling groups over the two-year period in which the QUANTIFY emissions were updated. p-TOMCAT is the only model with a reduction in the $\mathrm{O}_{3}$ column change for all three transport sectors between 
Table 2

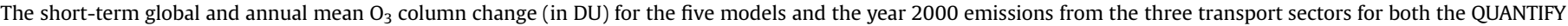
preliminary emissions (Hoor et al., 2009) and the QUANTIFY final emissions (this study).

\begin{tabular}{|c|c|c|c|c|c|c|c|c|c|c|}
\hline & \multicolumn{2}{|l|}{ Oslo CTM2 } & \multicolumn{2}{|l|}{ TM4 } & \multicolumn{2}{|l|}{ p-TOMCAT } & \multicolumn{2}{|l|}{ LMDz-INCA } & \multicolumn{2}{|l|}{$\mathrm{UCI}$} \\
\hline & Preliminary & Final & Preliminary & Final & Preliminary & Final & Preliminary & Final & Preliminary & Final \\
\hline ROAD & 0.99 & 1.38 & 0.72 & 0.88 & 0.59 & 0.51 & 0.77 & 0.94 & 0.80 & 1.25 \\
\hline SHIP & 0.96 & 1.02 & 0.71 & 0.68 & 0.82 & 0.65 & 0.67 & 0.55 & 0.84 & 1.04 \\
\hline AIR & 0.30 & 0.48 & 0.32 & 0.43 & 0.70 & 0.51 & 0.35 & 0.39 & 0.35 & 0.63 \\
\hline
\end{tabular}

preliminary and final QUANTIFY simulations in spite of increased $\mathrm{NO}_{\mathrm{x}}$ emissions.

Fig. 2 shows the global and annual mean RF for short-term $\mathrm{O}_{3}$, using the UiO radiation model, for the three transport sectors calculated by the five global chemistry models. Amongst the transport sectors, ROAD is largest, followed by SHIP and AIR sectors in four of the models. The five model average for the ROAD, SHIP and AIR sectors are 31,24 and $17 \mathrm{~mW} \mathrm{~m}^{-2}$, respectively. A composite, four model (without $\mathrm{UCI}$ ) mean of the $\mathrm{O}_{3}$ change is used to compare the radiation models. For this subset the UiO RF values are 30, 21 and $16 \mathrm{~mW} \mathrm{~m}^{-2}$ for the three sub-sectors, and the UoR calculations yield corresponding forcings of 28,19 and $17 \mathrm{~mW} \mathrm{~m}^{-2}$ indicating agreement to within about $10 \%$ in the RF calculations.

The relative spread in the RF among the models is within a factor of 2 for AIR, $\left(13-21 \mathrm{~mW} \mathrm{~m}^{-2}\right)$ and SHIP $\left(17-32 \mathrm{~mW} \mathrm{~m}^{-2}\right)$; by contrast for ROAD the spread in the RF is almost a factor of 3 $\left(15-42 \mathrm{~mW} \mathrm{~m}^{-2}\right)$. The model range in the sum of RF across all three sectors is less and ranges from 57 to $90 \mathrm{~mW} \mathrm{~m}^{-2}$.

The zonal-mean RFs of short-term $\mathrm{O}_{3}$ for the three transport sectors for all five models are shown in Fig. 3. The patterns of RF are similar for the four models Oslo CTM2, TM4, LMDz-INCA, and UCI, as governed by the global distribution of emissions for each sector, with ROAD dominating in the Northern Hemisphere, ROAD and SHIP being quite comparable in the Southern Hemisphere, and AIR being very small in the Southern Hemisphere. By contrast, the p-TOMCAT RF shows AIR as dominating in the Northern Hemisphere and comparably large also in the Southern Hemisphere.

The RF results are based on radiation calculations using the $100 \%$ perturbation in $\mathrm{O}_{3}$ that is derived by multiplying the ozone change resulting from the $5 \%$ perturbation in emissions by 20 (Grewe et al., 2010; Hoor et al., 2009). Hoor et al. (2009) showed that the sum of $\mathrm{O}_{3}$ changes from $5 \%$ perturbation in the individual ROAD, AIR and SHIP emissions equals that from a single calculation of the

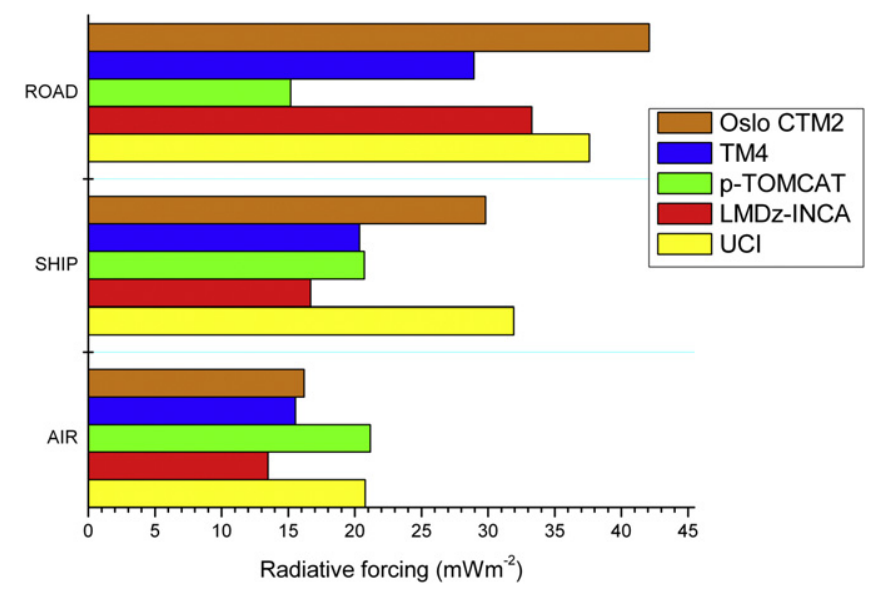

Fig. 2. Global and annual mean radiative forcing due to short-term $\mathrm{O}_{3}\left(\mathrm{~mW} \mathrm{~m}^{-2}\right)$ for year 2000 emissions from three transport sectors and five global chemistry models, as calculated using the UiO radiation schemes. combined emissions from all three sectors. Here, we investigate the difference between a scaled $5 \%$ reduction and a full $100 \%$ reduction of ROAD emissions with the Oslo CTM2: the $100 \%$ reduction gives column $\mathrm{O}_{3}$ changes that are 1.07 times greater than $20 \times 5 \%$; however, the non-linearity in the longwave RF reduces this to a factor of 1.03. Compared to the inter-model differences in the RF, the non-linear response to the magnitude of the perturbations is relatively small, and hence contributes little to the overall uncertainty.

Normalized radiative forcing from $\mathrm{O}_{3}$ (NRF) (RF divided by the change in the $\mathrm{O}_{3}$ column expressed in Dobson Units (DU)) is dependent on both the region and altitude of the resulting $\mathrm{O}_{3}$ change (Berntsen et al., 2000; Gauss et al., 2003). In all models, except LMDz-INCA, the AIR sector has a higher NRF than ROAD and SHIP with a mean of $36 \mathrm{~mW} \mathrm{~m}^{-2} \mathrm{DU}^{-1}$ with a range from 33 to $42 \mathrm{~mW} \mathrm{~m}^{-2} \mathrm{DU}^{-1}$. The values for ROAD and SHIP are $32 \mathrm{~mW} \mathrm{~m}^{-2} \mathrm{DU}^{-1}$ (range from 30 to $36 \mathrm{~mW} \mathrm{~m}^{-2} \mathrm{DU}^{-1}$ ) and $30 \mathrm{~mW} \mathrm{~m}^{-2} \mathrm{DU}^{-1}$ (range from 29 to $32 \mathrm{~mW} \mathrm{~m}^{-2} \mathrm{DU}^{-1}$ ), respectively. For the sum of RF across the three transport sectors, pTOMCAT yields the highest $\mathrm{NRF}\left(34 \mathrm{~mW} \mathrm{~m}^{-2} \mathrm{DU}^{-1}\right)$ and Oslo CTM2 the lowest $\left(31 \mathrm{~mW} \mathrm{~m}^{-2} \mathrm{DU}^{-1}\right)$. These NRF numbers show the largest spread for AIR. In some instances the agreement in the RF between models is a coincidence resulting from compensating differences in the NRF and the ozone change (as is the case for p-TOMCAT and UCI for AIR). Nevertheless, these comparisons in NRF show much less relative spread compared to the RF calculations, indicating that it is inter-model differences in the total $\mathrm{O}_{3}$ change that are mainly responsible for the differences in their $\mathrm{RF}$, rather than inter-model differences in the distribution of the $\mathrm{O}_{3}$ change.

\section{2. $\mathrm{CH}_{4}$}

The $\mathrm{O}_{3}$ precursor emissions change the atmospheric lifetime of $\mathrm{CH}_{4}$ due to changes in $\mathrm{OH}$ concentrations. The percentage changes in the $\mathrm{CH}_{4}$ lifetime due to destruction by $\mathrm{OH}$ (integrated between the surface and $50 \mathrm{hPa}$ for each model) are given in Table 3. For most models and most transport sectors, increased emissions lead to an increase in global $\mathrm{OH}$, a decrease in $\mathrm{CH}_{4}$ lifetime and hence a decrease in $\mathrm{CH}_{4}$ concentrations. The changes are largest for SHIP because of the different geographical pattern of emissions and background conditions as well as the mix of emitted components compared to the other sectors (Fuglestvedt et al., 2008; Hoor et al., 2009). Although AIR emissions have the largest impact on $\mathrm{CH}_{4}$ on a per unit $\mathrm{NO}_{\mathrm{x}}$ emission basis, SHIP and ROAD each have nearly ten times larger $\mathrm{NO}_{\mathrm{x}}$ emissions. Unlike the results in Hoor et al. (2009), where all models (including p-TOMCAT) and all sectors showed a decrease in $\mathrm{CH}_{4}$ lifetime, the current p-TOMCAT version using the final QUANTIFY emissions calculates a small increase in $\mathrm{CH}_{4}$ lifetime for ROAD. Our analysis finds that p-TOMCAT has a much stronger response of the $\mathrm{OH}$ concentrations to emissions of $\mathrm{CO}$ and $\mathrm{NMHC}$ than the other models and this overwhelms the effect of the $\mathrm{NO}_{\mathrm{x}}$ emissions. This model has lower CO concentrations than the four other models, which can partly explain the different impact of the ROAD emissions. 

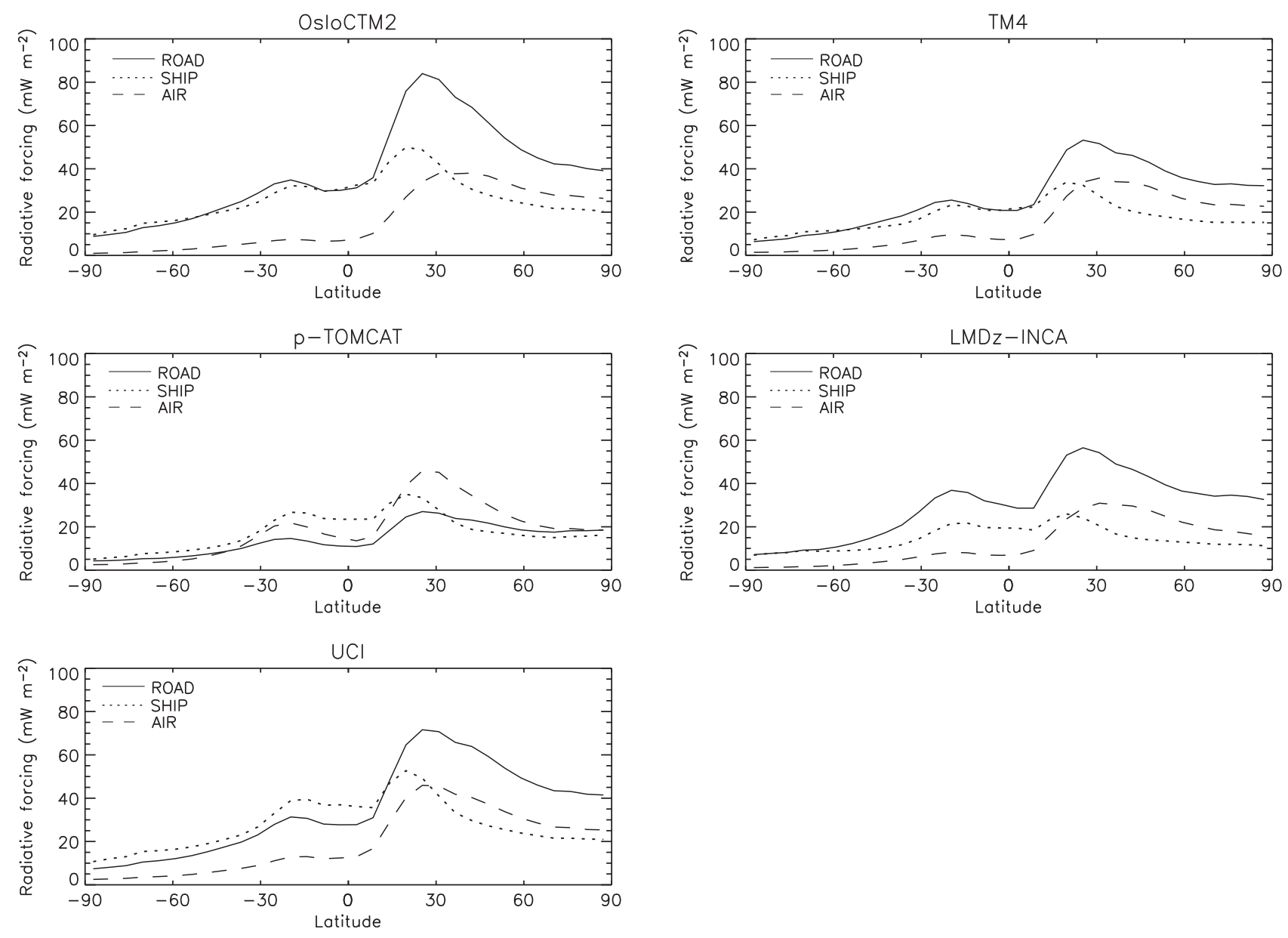

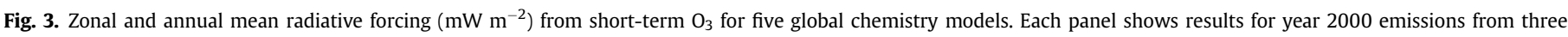
transport sectors.

The resulting RF for year 2000 due to $\mathrm{CH}_{4}$ change from the transport sector (including the transient effect but not the $\mathrm{CH}_{4}$ induced changes in $\mathrm{O}_{3}$ and stratospheric water vapour) is shown in Fig. 4. This $\mathrm{CH}_{4} \mathrm{RF}$ is larger for SHIP than ROAD and AIR. The intermodel difference in the $\mathrm{CH}_{4} \mathrm{RF}$ is rather small for SHIP, with a spread of only $8 \mathrm{~mW} \mathrm{~m}^{-2}$ for an average RF of $-27 \mathrm{~mW} \mathrm{~m}^{-2}$. For AIR, all models show a negative RF, with a mean of $-7.3 \mathrm{~mW} \mathrm{~m}^{-2}$ and a relatively higher spread of $4.4 \mathrm{~mW} \mathrm{~m}^{-2}$. The ROAD RF from $\mathrm{CH}_{4}$ varies little among four global models, -12 to $-14 \mathrm{~mW} \mathrm{~m}^{-2}$, but $\mathrm{p}$-TOMCAT gives $+1 \mathrm{~mW} \mathrm{~m}^{-2}$, reducing the magnitude of the mean $\mathrm{RF}$ for ROAD for the $\mathrm{CH}_{4}$ lifetime to $-10 \mathrm{~mW} \mathrm{~m}^{-2}$.

\section{3. $\mathrm{RF}$ due to short-term $\mathrm{O}_{3}$ and $\mathrm{CH}_{4}$ changes combined}

The net $\mathrm{RF}$ of short-term $\mathrm{O}_{3}$ and long-term $\mathrm{CH}_{4}$ combined (and now including the $\mathrm{CH}_{4}$ impacts on $\mathrm{O}_{3}$ and stratospheric water

Table 3

$\mathrm{CH}_{4}$ lifetimes (yr) due to destruction by $\mathrm{OH}$ (between the surface and $50 \mathrm{hPa}$ ) for the base case and the relative changes due to year 2000 emissions from three transport sectors - the values are derived from a 5\% change in emissions for each sector and then multiplied by 20 . The feedback effect of changes in $\mathrm{CH}_{4}$ on its own lifetime is not included in this Table.

\begin{tabular}{lcrccc}
\hline & Oslo CTM2 & \multicolumn{1}{c}{ TM4 } & p-TOMCAT & LMDz-INCA & UCI \\
\hline Base (years) & 8.29 & 8.59 & 9.38 & 9.02 & 7.81 \\
Road \% & -1.77 & -1.62 & 0.12 & -1.54 & -1.78 \\
Ship \% & -3.74 & -4.14 & -3.45 & -3.14 & -4.24 \\
Air \% & -0.81 & -1.22 & -1.55 & -1.04 & -1.57 \\
\hline
\end{tabular}

vapour) are shown in Fig. 5 . All five models have a positive net $R F$ for ROAD and AIR and a negative RF for SHIP. For ROAD, the net forcing varies from 9.3 to $21 \mathrm{~mW} \mathrm{~m}^{-2}$, with a mean of $16 \mathrm{~mW} \mathrm{~m}^{-2}$. For SHIP, the range is -12 to $-25 \mathrm{~mW} \mathrm{~m}^{-2}$ with a mean of $-18 \mathrm{~mW} \mathrm{~m}^{-2}$. Although the general agreement in Fig. 5 is quite encouraging in terms of absolute RF, the degree of agreement is less

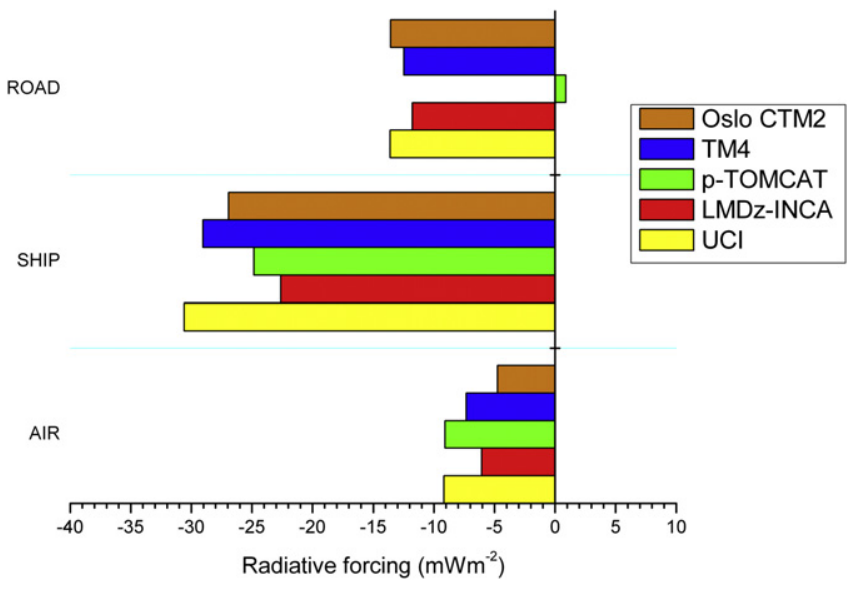

Fig. 4. Global and annual mean radiative forcing for the year 2000 due to $\mathrm{CH}_{4}$ changes $\left(\mathrm{mW} \mathrm{m}^{-2}\right.$ ) accounting for the time-history of the emissions (see text for details) for three transport sectors and five global chemistry models. 


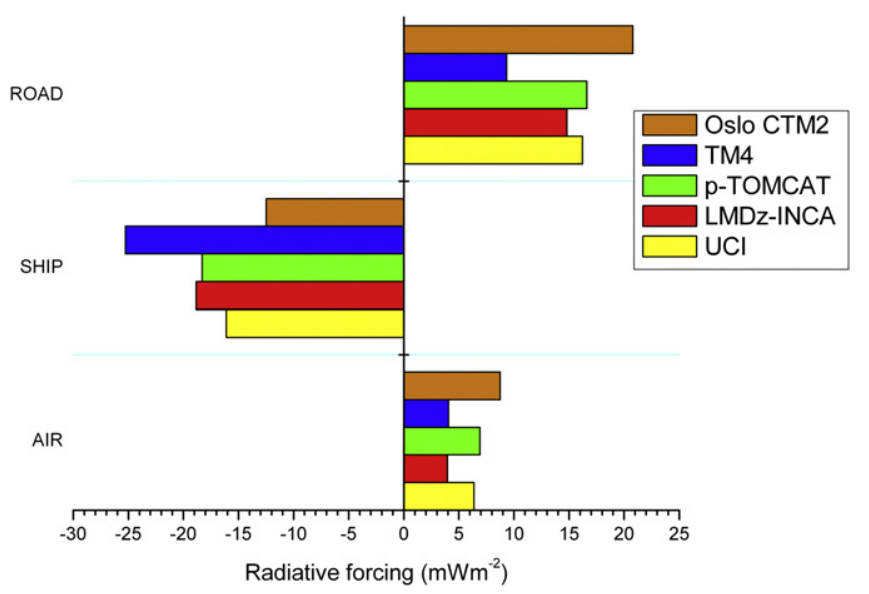

Fig. 5. Net $\mathrm{RF}$ of $\mathrm{O}_{3}$ and $\mathrm{CH}_{4}$ (including stratospheric water vapour) in year 2000 accounting for the time-history of the emissions (see text for details) for three transport sectors and five global chemistry models.

than that seen in Fig. 4 (p-TOMCAT for ROAD excepted). This is because the models show a differing amount of cancellation between the short-term $\mathrm{O}_{3} \mathrm{RFs}$ and $\mathrm{CH}_{4}$. This uncertainty in the long-term $\mathrm{RF}\left(\mathrm{CH}_{4}\right.$ plus induced $\mathrm{O}_{3}$ changes) may be underestimated since we used a single conversion factor for the $\mathrm{CH}_{4}$ feedback on its own lifetime, and a single factor for the RF due to the $\mathrm{CH}_{4}$-induced ozone change and the stratospheric $\mathrm{H}_{2} \mathrm{O}$ change. For AIR, the spread is from 4.1 to $8.7 \mathrm{~mW} \mathrm{~m}^{-2}$ with a mean of $6.0 \mathrm{~mW} \mathrm{~m}^{-2}$. Compared to the multi-model mean, Oslo CTM2 is always more positive, by several 10's of percent, TM4 is always more negative by several tens of percent, while deviations from the mean for LMDz-INCA, UCI and p-TOMCAT are generally smaller and all are within $10 \%$ of the multi-model mean for two of the three sectors.

To derive the uncertainties in the RF, we use uncertainties in the emissions (Fuglestvedt et al., 2008), and simulations of distribution changes and radiative forcing performed in this study combined with Monte Carlo simulations (Boucher and Haywood, 2001). For $\mathrm{O}_{3}$ and the $\mathrm{CH}_{4}$ lifetime effect we use the difference in the global chemistry models as one standard deviation representative for the uncertainty in distributions for each of the transport sectors. The uncertainty in the $\mathrm{CH}_{4}$ impact on $\mathrm{O}_{3}$ takes into account uncertainty in the model change in $\mathrm{CH}_{4}$ and $\mathrm{O}_{3}$ in addition to the uncertainty in emissions. For stratospheric water vapour uncertainties in the emissions, $\mathrm{CH}_{4}$ change and the radiative transfer are considered. The latter is taken from an intercomparison study with an uncertainty of $30 \%$ (Myhre et al., 2009). The derived uncertainties (one standard deviation) are $13 \mathrm{~mW} \mathrm{~m}^{-2}(81 \%), 10 \mathrm{~mW} \mathrm{~m}^{-2}(55 \%)$, and $5 \mathrm{~mW} \mathrm{~m}^{-2}$ (81\%) for ROAD, SHIP, and AIR, respectively. The dominating contributor to the uncertainty is the short-term $\mathrm{O}_{3}$.

\section{Climate emission metrics for aviation $\mathrm{NO}_{\mathrm{x}}$ emissions}

Fuglestvedt et al. (2010) reported values (as well as a number of important caveats) for the GWP and GTP for $\mathrm{NO}_{\mathrm{x}}$ emissions from aviation using available results in the literature. They found substantial differences in the derived GWPs and GTPs, which included a difference in sign for some time horizons $(\mathrm{H})$. The results derived here allow a cleaner comparison of GWPs and GTPS between global chemistry models, as they are derived using the same emissions and emission perturbations, the same experimental design and use the same radiative transfer scheme to calculate the RF. Thus the spread in results gives us a measure of the uncertainty in the global chemical modelling of aviation's impact on atmospheric chemistry. We do not present values for the other sectors, as the ozone changes for these are influenced by $\mathrm{CO}$ and $\mathrm{NMHC}$ emissions as well as $\mathrm{NO}_{\mathrm{x}}$.

The Fuglestvedt et al. (2010) methodology is adopted here for the calculation of GWPs and GTPs, although we also include the effect of $\mathrm{CH}_{4}$ changes on stratospheric water vapour. In line with the conventional definitions of GWP and GTP, $\mathrm{CO}_{2}$ is used as the reference gas. The GTP values are somewhat sensitive to the model used to calculate the temperature change, and the assumed climate sensitivity. Appendix 2 in Fuglestvedt et al. (2010) describes the method used here, which is based on fits to coupled ocean-atmosphere general circulation model experiments, which have an equilibrium climate sensitivity to a doubling of $\mathrm{CO}_{2}$ of $3.9 \mathrm{~K}$. The $\mathrm{CH}_{4}$ lifetimes given in Table 3 are multiplied by 1.4 to give the $\mathrm{CH}_{4}$ perturbation lifetimes (which accounts for the effect of a change in $\mathrm{CH}_{4}$ on its own lifetime). Table 4 shows the specific RFs (in $\mathrm{W} \mathrm{m}^{-2}$ $\left.\left(\mathrm{kgN} \mathrm{yr}^{-1}\right)\right)$ for the short-lived ozone, methane-induced ozone and methane for the 5 models, as well as the multi-model mean, which are required as input to the GWP and GTP calculations.

The resulting GWP values for three time horizons $(H=20,100$ and 500 years) are shown in Table $5 a$, and for the GTPs $(\mathrm{H}=20,50$ and 100 years), in Table $5 \mathrm{~b}$. In both tables, the values are split into three components - the short-term $\mathrm{O}_{3}$ effect resulting directly from the $\mathrm{NO}_{\mathrm{x}}$ emissions, the decadal $\mathrm{CH}_{4}$-induced $\mathrm{O}_{3}$ change and the $\mathrm{CH}_{4}$ change itself, which is scaled to include the stratospheric water vapour effect (which is 0.15 of the direct effect). The range of results given in Fuglestvedt et al. (2010) is also shown. Considering the GWP, the results indicate at first sight that the range from the present models - an indicator of the uncertainty in the GWP - is no smaller than that derived in Fuglestvedt et al. (2010). For $H=20$ years, there is a spread of a factor of 3; for $H=100$ and 500 years, the different models do not even agree in sign. For GTP, the situation is similar: for $H=20$ and 50 years, the spread is no less than in Fuglestvedt et al. (2010), while for $H=100$ years, there is disagreement in sign.

However, Table 5 reveals important patterns that give hope that the reasons for the model differences can be resolved. For all metrics and all time horizons, values from the Oslo CTM2 are clearly the most positive (as is true also for the net forcings for all sectors shown in Fig. 5); for GWP $(H=20)$, GWP $(H=100)$ and GTP $(H=100)$ it is the only model generating a positive value. Removing the Oslo CTM2 model, markedly reduces the range in both the GWPs and GTPs. For example GWP $(H=100)$ changes from -21 to 67 , to -21 to -6.3 ; and GTP $(H=100)$ changes from -5.8 to 7.9 to -5.8 to -4.6 . Much less markedly, TM4 is the most negative for all GWP time horizons, and p-TOMCAT is generally the most negative for GTP $(H=50)$ and $\operatorname{GTP}(H=100)$.

This behaviour seems largely a result of one characteristic of the models - the ratio of the percentage change in $\mathrm{CH}_{4}$ lifetime to the $\mathrm{O}_{3}$ column change. Using Tables 2 and 3, the values for AIR range from $-1.7 \% \mathrm{DU}^{-1}$ for Oslo CTM2, $-2.8 \% \mathrm{DU}^{-1}$ for TM $4,-2.5 \% \mathrm{DU}^{-1}$ for $\mathrm{UCI},-2.7 \% \mathrm{DU}^{-1}$ for LMDz-INCA to $-3.0 \% \mathrm{DU}^{-1}$ for $\mathrm{p}$-TOMCAT.

Table 4

Steady-state radiative forcings (in $\mathrm{W} \mathrm{m}^{-2}\left(\mathrm{kgN} \mathrm{yr}^{-1}\right)$ ) for sustained $\mathrm{AIR} \mathrm{NO}_{\mathrm{x}}$ emissions for each of the 5 models and the mean of the 5 models. In this table, for example, $1.94 \mathrm{E}-11$ denotes $1.94 \times 10^{-11}$ etc.

\begin{tabular}{llll}
\hline & Short-lived ozone & Methane-induced ozone & methane \\
\hline Oslo CTM2 & $1.94 \mathrm{E}-11$ & $-3.68 \mathrm{E}-12$ & $-1.01 \mathrm{E}-11$ \\
TM4 & $1.86 \mathrm{E}-11$ & $-5.52 \mathrm{E}-12$ & $-1.51 \mathrm{E}-11$ \\
p-TOMCAT & $2.54 \mathrm{E}-11$ & $-7.02 \mathrm{E}-12$ & $-1.92 \mathrm{E}-11$ \\
LMDz-INCA & $1.62 \mathrm{E}-11$ & $-4.69 \mathrm{E}-12$ & $-1.29 \mathrm{E}-11$ \\
UCI & $2.49 \mathrm{E}-11$ & $-7.10 \mathrm{E}-12$ & $-1.94 \mathrm{E}-11$ \\
Mean & $2.09 \mathrm{E}-11$ & $-5.60 \mathrm{E}-12$ & $-1.53 \mathrm{E}-11$ \\
\hline
\end{tabular}


Table 5

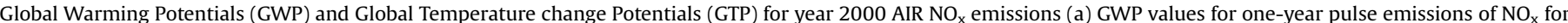

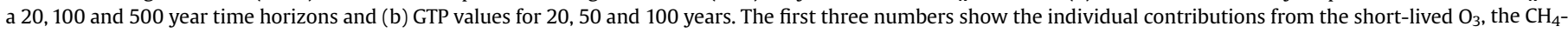

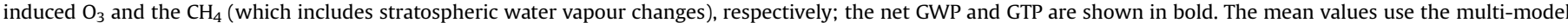

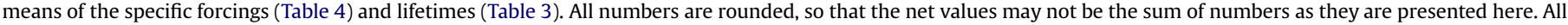
values are on a per $\mathrm{kg} \mathrm{N}$ basis and are relative to $\mathrm{CO}_{2}$. The GTP values are specific to a given value of climate sensitivity - see text for details.

\begin{tabular}{|c|c|c|c|}
\hline (a) GWP & $H=20$ & $H=100$ & $H=500$ \\
\hline Oslo CTM2 & $785-115-333=338$ & $223-41-116=67$ & $68-12-5=20$ \\
\hline TM4 & $753-170-490=92$ & $214-61-174=-21$ & $65-19-53=-6.3$ \\
\hline p-TOMCAT & $1028-209-601=218$ & $292-78-221=-6.3$ & $89-24-67=-2.0$ \\
\hline LMDz-INCA & $656-142-411=103$ & $186-52-148=-14$ & $57-16-45=-4.2$ \\
\hline $\mathrm{UCI}$ & $1008-226-654=128$ & $287-78-223=-15$ & $87-24-68=-4.5$ \\
\hline Mean & $846-173-496=177$ & $241-62-176=2.7$ & $73-19-54=0.8$ \\
\hline Range of net & 92 to 338 & -21 to 67 & -6.3 to 20 \\
\hline Fuglestvedt et al. (2010) range of net & 120 to 470 & -2.1 to 71 & -0.7 to 22 \\
\hline (b) GTP & $H=20$ & $H=50$ & $H=100$ \\
\hline Oslo CTM2 & $248-271-97=-121$ & $39-55-20=-37$ & $32-18-6.2=7.9$ \\
\hline TM4 & $238-406-145=-313$ & $37-87-31=-81$ & $30-27-9.4=-5.6$ \\
\hline p-TOMCAT & $324-510-183=-369$ & $51-122-44=-115$ & $41-35-12.3=-5.8$ \\
\hline LMDz-INCA & $206-343-123=-259$ & $32-78-28=-74$ & $26-23-8.1=-4.7$ \\
\hline UCI & $318-526-188=-396$ & $50-100-36=-86$ & $41-34-11.7=-4.6$ \\
\hline Mean & $267-412-147=-292$ & $42-88-32=-79$ & $34-27-9.5=-4.1$ \\
\hline Range of net & -396 to -121 & -115 to -37 & -5.8 to 7.9 \\
\hline Fuglestvedt et al. (2010) range of net & -590 to -200 & -210 to -59 & -9.5 to 7.6 \\
\hline
\end{tabular}

Hence, for the Oslo CTM2 model the compensating effect of the negative forcing due to $\mathrm{CH}_{4}$ and its resulting effect on stratospheric water vapour and $\mathrm{O}_{3}$ is smaller than for the other models. The differences in $\mathrm{CH}_{4}$ lifetime between the models (Table 4) have only a small influence on the range of results.

If the reason why the models differ in ratio of $\mathrm{CH}_{4}$ change to $\mathrm{O}_{3}$ change can be understood, there is hope for a marked reduction in the inter-model range in the estimated net $R F$ from transport and in metrics such as the GWP and GTP. However, as is clear in Table 5, even when models agree in the net value of a metric, the individual components contributing to this net value can be quite different for example, UCI and p-LMDz-INCA agree well in the net for both metrics and most time horizons, but disagree significantly for the three components; this effect is traceable to the larger change in $\mathrm{O}_{3}$ in UCI compared to LMDz-INCA (see Table 2).

\section{Conclusions}

We have investigated the RF for the year 2000 due to changes in $\mathrm{O}_{3}$ and $\mathrm{CH}_{4}$ caused by the transport sector, using five global chemistry models and two radiation models. We find the difference between ROAD, SHIP and AIR to be robust across all models. For the year 2000, this study reduces the $\mathrm{CH}_{4}$ and $\mathrm{CH}_{4}$-induced $\mathrm{O}_{3}$ impacts to account for the slower response of $\mathrm{CH}_{4}$ perturbations to changes in $\mathrm{OH}$. It also includes the effect of $\mathrm{CH}_{4}$ changes on stratospheric water vapour. The results are also used to present values of GWP and GTP for AIR $\mathrm{NO}_{\mathrm{x}}$ emissions which are based on a range of global chemistry models adopting the same experimental design.

Fuglestvedt et al. (2008) found, based on one global chemistry transport model and one radiative transfer model, a year $2000 \mathrm{RF}$ for the combined effect of $\mathrm{O}_{3}$ and $\mathrm{CH}_{4}$ amounting to $42 \mathrm{~mW} \mathrm{~m}^{-2}$ for ROAD, $-11 \mathrm{~mW} \mathrm{~m}^{-2}$ for SHIP and $12 \mathrm{~mW} \mathrm{~m}^{-2}$ for AIR, based on a different set of emissions (see Fig. 1). The multi-model means obtained here are $16 \mathrm{~mW} \mathrm{~m}^{-2},-18 \mathrm{~mW} \mathrm{~m}^{-2}$ and $6.0 \mathrm{~mW} \mathrm{~m}^{-2}$ respectively. The ROAD and AIR are significantly smaller in the present analysis than in (Fuglestvedt et al., 2008), while SHIP is significantly more negative. Various factors explain the differences. First, the emissions are different. As a consequence, a lower ozone production (at least for ROAD with lower CO and NHMC emissions) and hence less net positive radiative forcing is calculated. Second, the secondary consequences of methane changes included here (i.e. responses in $\mathrm{O}_{3}$ and stratospheric $\mathrm{H}_{2} \mathrm{O}$ ) increase the negative radiative forcings. Third, the Oslo CTM2, which was used in the Fuglestvedt et al. (2008) study is seen here to produce results at the upper end of the spectrum, compared with the multi-model mean. All three factors act together to lower the calculated radiative forcing from the transport sectors compared to the values in Fuglestvedt et al. (2008). The RF for the combined effect of $\mathrm{O}_{3}$ and $\mathrm{CH}_{4}$ can be compared to the RF due to $\mathrm{CO}_{2}$ which has previously been estimated to be $150 \mathrm{~mW} \mathrm{~m}^{-2}$, $35 \mathrm{~mW} \mathrm{~m}^{-2}, 21 \mathrm{~mW} \mathrm{~m}^{-2}$ for ROAD, SHIP, and AIR, respectively (Fuglestvedt et al., 2008).

The results reported here with the QUANTIFY inventories can be compared with the previous Hoor et al. (2009) results using preliminary QUANTIFY inventories, where the multi-model means were $7.3 \mathrm{~mW} \mathrm{~m}^{-2},-26 \mathrm{~mW} \mathrm{~m}^{-2}$ and $2.9 \mathrm{~mW} \mathrm{~m}^{-2}$ for ROAD, SHIP and AIR, respectively. For SHIP and AIR part of the difference is due to account being taken here of the lack of steady state of the $\mathrm{CH}_{4}$ field with the changed $\mathrm{OH}$ field, which reduces the size of the $\mathrm{CH}_{4}$ offset to the positive short-term $\mathrm{O}_{3}$ forcing. The factor of more than two change for ROAD has a number of identified reasons (emissions, model updates, and method for $\mathrm{CH}_{4} \mathrm{RF}$ calculations); the short-term $\mathrm{O}_{3}$ forcing is only changed by about $10 \%$ while the offset resulting from the changed $\mathrm{OH}$ field is now smaller. Based on the much higher emissions of CO and NMHC in Fuglestvedt et al. (2008) it is expected that the $\mathrm{O}_{3} \mathrm{RF}$ for ROAD was higher in that study compared to Hoor et al. (2009) and this study (see Fig. 1). On robustness and uncertainties for road transport, the $\mathrm{O}_{3} \mathrm{RF}$ is highly dependent on the background $\mathrm{NO}_{\mathrm{x}}$ emissions used in the model, including those from power generation, agriculture, lightning and biomass burning.

The inter-model absolute differences are smaller when the combined effects of $\mathrm{O}_{3}$ and $\mathrm{CH}_{4} \mathrm{RFs}$ are calculated than they are for the, short-term $\mathrm{O}_{3} \mathrm{RF}$ alone. Nevertheless, the combined $\mathrm{O}_{3}$ and $\mathrm{CH}_{4} \mathrm{RF}$ from individual models can deviate by many tens of percent from the multi-model mean. One significant factor in these differences, and the difference in the aviation climate emission metrics, is the ratio of the percentage change in $\mathrm{CH}_{4}$ lifetime to the column $\mathrm{O}_{3}$ change. If the underlying reasons for this ratio could be understood, there is the possibility of markedly decreasing the intermodel differences. 
The RF resulting from the effect of transport-related emissions on ozone and methane reported here must be combined with estimates of the transport-related $\mathrm{RF}$ from aerosols and $\mathrm{CO}_{2}$ (e.g. Balkanski et al., 2010) to improve understanding of the overall impact of the transport sector on climate.

\section{Acknowledgements}

The QUANTIFY project is funded by the European Union within the 6th Framework Programme under contract 003893 and the Norwegian Research Council. The reviewers are thanked for their helpful comments.

\section{References}

Balkanski, Y., Myhre, G., Gauss, M., Rädel, G., Highwood, E.J., et al., 2010. Direct radiative effect of aerosols emitted by transport: from road, shipping and aviation. Atmos. Chem. Phys. 10, 4477-4489.

Berglen, T.F., Berntsen, T.K., Isaksen, I.S.A., Sundet, J.K., 2004. A global model of the coupled sulfur/oxidant chemistry in the troposphere: the sulfur cycle. J. Geophys. Res. 109 (D19), D19310. doi:10.1029/2003JD003948.

Berntsen, T.K., Fuglestvedt, J.S., Joshi, M.M., Shine, K.P., Stuber, N., et al., 2005. Response of climate to regional emissions of ozone precursors: sensitivities and warming potentials. Tellus 57 (4), 283-304.

Berntsen, T.K., Myhre, G., Stordal, F., Isaksen, I.S.A., 2000. Time evolution of tropospheric ozone and its radiative forcing. J. Geophys. Res. 105 (D7), 8915-8930.

Boucher, O., Haywood, J., 2001. On summing the components of radiative forcing of climate change. Clim. Dynam. 18 (3-4), 297-302.

Edwards, J.M., Slingo, A., 1996. Studies with a flexible new radiation code. I: Choosing a configuration for a large-scale model. Q.J.R. Meteorol.Soc. 122, 689-719.

Folberth, G.A., Hauglustaine, D.A., Lathiere, J., Brocheton, F., 2006. Interactive chemistry in the Laboratoire de Meteorologie Dynamique general circulation model: model description and impact analysis of biogenic hydrocarbons on tropospheric chemistry. Atmos. Chem. Phys. 6, 2273-2319.

Forster, P., Ramaswamy, V., Artaxo, P., Berntsen, T., Betts, R., et al., 2007. Changes in atmospheric constituents and in radiative forcing. In: Solomon, S., Qin, D. Manning, M., Chen, Z., Marquis, M., et al. (Eds.), Climate Change 2007: The Physical Science Basis. Contribution of Working Group I to the Fourth Assessment Report of the Intergovernmental Panel on Climate Change. Cambridge University Press, United Kingdom and New York, NY, USA.

Fuglestvedt, J., Berntsen, T., Myhre, G., Rypdal, K., Skeie, R.B., 2008. Climate forcing from the transport sectors. Proc. Natl. Acad. Sci. U S A 105 (2), 454-458.

Fuglestvedt, J.S., Berntsen, T.K., Isaksen, I.S.A., Mao, H.T., Liang, X.Z., et al., 1999. Climatic forcing of nitrogen oxides through changes in tropospheric ozone and methane; global 3D model studies. Atmos. Environ. 33 (6), 961-977.

Fuglestvedt, J.S., Shine, K.P., Cook, J., Berntsen, T., Lee, D.S., et al., 2010. Assessment of transport impacts on climate and ozone: metrics. Atmos. Environ. 44, 4648-4677. doi:10.1016/j.atmosenv.2009.04.044.

Gauss, M., Myhre, G., Isaksen, I.S.A., Grewe, V., Pitari, G., et al., 2006. Radiative forcing since preindustrial times due to ozone change in the troposphere and the lower stratosphere. Atmos. Chem. Phys. 6, 575-599.

Gauss, M., Myhre, G., Pitari, G., Prather, M.J., Isaksen, I.S.A., et al., 2003. Radiative forcing in the 21st century due to ozone changes in the troposphere and the lower stratosphere. J. Geophys. Res. 108 (D9), 4292.

Grewe, V., Stenke, A., 2008. AirClim: an efficient tool for climate evaluation of aircraft technology. Atmos. Chem. Phys. 8 (16), 4621-4639.

Grewe, V., Tsati, E., Hoor, P., 2010. On the attribution of contributions of atmospheric trace gases to emissions in atmospheric model applications. Geosci. Model Dev. 3, 487-499.

Hauglustaine, D.A., Hourdin, F., Jourdain, L., Filiberti, M.A., Walters, S., et al, 2004 Interactive chemistry in the Laboratoire de Meteorologie Dynamique general circulation model: description and background tropospheric chemistry evaluation. J. Geophys. Res. 109 (D4), D04314.

Hoor, P., Borken-Kleefeld, J., Caro, D., Dessens, O., Endresen, O., et al., 2009. The impact of traffic emissions on atmospheric ozone and $\mathrm{OH}$ : results from QUANTIFY. Atmos. Chem. Phys. 9 (9), 3113-3136.

Hsu, J., Prather, M.J., Wild, O., 2005. Diagnosing the stratosphere-to-troposphere flux of ozone in a chemistry transport model. J. Geophys. Res. 110 (D19), D19305.
Isaksen, I.S.A., Zerefos, C., Kourtidis, K., Meleti, C., Dalsoren, S.B., et al., 2005 Tropospheric ozone changes at unpolluted and semipolluted regions induced by stratospheric ozone changes. J. Geophys. Res. 110 (D2), D02302.

Kvalevåg, M.M., Myhre, G., 2007. Human impact on direct and diffuse solar radiation during the industrial era. J. Clim. 20 (19), 4874-4883.

Lelieveld, J., Crutzen, P.J., Dentener, F.J., 1998. Changing concentration, lifetime and climate forcing of atmospheric methane. Tellus 50 (2), 128-150.

Myhre, G., Karlsdottir, S., Isaksen, I.S.A., Stordal, F., 2000. Radiative forcing due to changes in tropospheric ozone in the period 1980 to 1996. J. Geophys. Res. 105 (D23), 28935-28942.

Myhre, G., Kvalevag, M., Radel, G., Cook, J., Shine, K.P., et al., 2009. Intercomparison of radiative forcing calculations of stratospheric water vapour and contrails. Meteorol. Z. 18 (6), 585-596.

Myhre, G., Nilsen, J.S., Gulstad, L., Shine, K.P., Rognerud, B., et al., 2007. Radiative forcing due to stratospheric water vapour from $\mathrm{CH}_{4}$ oxidation. Geophys. Res. Lett. 34 (1), L01807.

Naik, V., Mauzerall, D., Horowitz, L., Schwarzkopf, M.D., Ramaswamy, V., et al., 2005. Net radiative forcing due to changes in regional emissions of tropospheric ozone precursors. J. Geophys. Res. 110 (D24), D24306.

O'Connor, F., Carver, G., Savage, N., Pyle, J., Methven, J., et al., 2005. Comparison and visualisation of high-resolution transport modelling with aircraft measurements. Atmos. Sci. Lett. 6, 164-170. doi:10.1002/asl.111.

Prather, M., Ehhalt, D., Dentener, F., Derwent, R, Dlugokencky, E, et al, 2001 Atmospheric chemistry and greenhouse gases. e. a.. In: Houghton, J.T. (Ed.), Climate Change 2001: The Scientific Basis, Contribution of Working Group I to the Third Assessment Report of the Intergovernmental Panel on Climate Change. Cambridge University Press, Cambridge, United Kingdom and New York, NY, USA, pp. 239-287.

Prather, M.J., 1994. Lifetimes and eigenstates in atmospheric chemistry. Geophys. Res. Lett. 21 (9), 801-804.

Ramaswamy, V., Boucher, O., Haigh, J., Hauglustaine, D., Haywood, J., et al., 2001. Radiative forcing of climate change. In: Houghton, J.T., et al. (Eds.), Climate Change 2001: The Scientific Basis, Contribution of Working Group I to the Third Assessment Report of the Intergovernmental Panel on Climate Change. Cambridge University Press, Cambridge, United Kingdom and New York, NY, USA pp. 349-416.

Shindell, D.T, Faluvegi, G., Bell, N., Schmidt, G.A., 2005. An emissions-based view of climate forcing by methane and tropospheric ozone. Geophys. Res. Lett. 32 (4), L04803.

Shindell, D.T., Faluvegi, G., Koch, D.M., Schmidt, G.A., Unger, N., et al., 2009 Improved attribution of climate forcing to emissions. Science 326 (5953), 716-718.

Sitch, S., Cox, P.M., Collins, W.J., Huntingford, C., 2007. Indirect radiative forcing of climate change through ozone effects on the land-carbon sink. Nature 448 (7155), 791-794.

Skeie, R.B., Fuglestvedt, J., Berntsen, T., Lund, M.T., Myhre, G., et al., 2009. Globa temperature change from the transport sectors: historical development and future scenarios. Atmos. Environ. 43 (39), 6260-6270.

Uherek, E., Halenka, T., Borken-Kleefeld, J., Balkanski, Y., Berntsen, T., et al., 2010 Transport impacts on atmosphere and climate: land transport. Atmos. Environ. 44, 4772-4816.

Unger, N., Shindell, D.T., Koch, D.M., Amann, M., Cofala, J., et al., 2006. Influences of man-made emissions and climate changes on tropospheric ozone, methane and sulfate at 2030 from a broad range of possible futures. J. Geophys. Res. 111 (D12), D12313.

van Noije, T.P.C., Eskes, H.J., Dentener, F.J., Stevenson, D.S., Ellingsen, K., et al., 2006 Multi-model ensemble simulations of tropospheric $\mathrm{NO}_{2}$ compared with GOME retrievals for the year 2000. Atmos. Chem. Phys. 6, 2943-2979.

Wild, O., Prather, M.J., 2000. Excitation of the primary tropospheric chemical mode in a global three-dimensional model. J. Geophys. Res. 105 (D20), 24647-24660.

Wild, O., Prather, M.J., Akimoto, H., 2001. Indirect long-term global radiative cooling from $\mathrm{NO}_{\mathrm{x}}$ emissions. Geophys. Res. Lett. 28 (9), 1719-1722.

Wild, O., Sundet, J.K., Prather, M.J., Isaksen, I.S.A., Akimoto, H., et al., 2003. Chemica transport model ozone simulations for spring 2001 over the western Pacific: comparisons with TRACE-P lidar, ozonesondes, and Total Ozone Mapping Spectrometer columns. J. Geophys. Res. 108 (D21), 8826.

Williams, J.E., Scheele, M.P., van Velthoven, P.F.J., Cammas, J.P., Thouret, V., et al., 2009. The influence of biogenic emissions from Africa on tropical tropospheric ozone during 2006: a global modeling study. Atmos. Chem. Phys. 9 (15), 5729-5749.

Williams, J.E., Scheele, M.P., van Velthoven, P.F.J., Thouret, V., Saunois, M., et al., 2010. The influence of biomass burning on tropospheric composition over the tropical Atlantic Ocean and Equatorial Africa during the West African monsoon in 2006. Atmos. Chem. Phys. Discuss. 10, 7507-7552. 